\title{
JUURNAL.RU
}

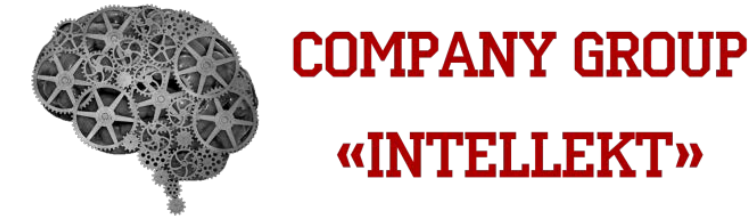

Никитина В.С., Яминева Э.З. Бамкирский государственный университет Уфа, Россия

doi: 10.18411/lj2016-6-5-02

\section{Модификация инулина сульфоаминокислотой и прогнозирование биологической активности конъюгата}

Растительные полисахариды обладают высокой биологической, активностью и широко распространены в природе. Они представляют интерес как неспецифические транспортные макромолекулы, улучшающие доставку лекарственных веществ к биомишени. Кроме того, в результате введения в молекулы полисахаридов функциональных групп или низкомолекулярных фрагментов приводит к созданию новых лекарственных веществ [1,2]. Поэтому работы по данному направлению являются актуальными. При обработке литературных данных оказалось, что большинство схем модификации структуры растительных полисахаридов разработано в настоящее время только для целлюлозы и декстрана. В фармацевтической промышленности особый интерес представляет полифруктозан - инулин в качестве заменителя сахара в терапии диабета. Синтоном для модификации молекулы инулина стал интересен, на наш взгляд, таурин. Таурин - это сульфокислота, которая образуется в результате метаболизма из аминокислоты цистеина [3]. Таурин участвует в обмене липидов, улучшает энергетические и обменные процессы. Его широко применяют как антидиабетическое средство благодаря воздействию на органы, обычно пораженные у диабетиков (почки, зрение, нервная система) и как средство, контролирующее уровень сахара в крови [3].Синтез конъюгата инулина с таурином проводили по методике, описанной нами ранее [4]. 
Конъюгат инулина с таурином представляет собой аморфный порошок светложелтого цвета, растворимый в воде, концентрированном этиловом спирте, но не растворимый в органических растворителях. Предполагается, что введение в структуру инулина низкомолекулярного терапевтического вещества приведет к тому, что биополимер приобретет новые свойства и возникнет возможность создания новой формы лекарственного препарата.

Прогноз биологической активности конъюгата инулина с таурином осуществляли с помощью компьютерной программы и базы данных PASS (Prediction of Activity Spectra of Substances) [5], которая позволяет прогнозировать основные фармакотерапевтические эффекты вещества, биохимические механизмы, на которых основаны эти действия и возможные побочные (токсические) влияния. Прогноз в программе осуществляется по структурной формуле химического соединения и основывается на анализе базы данных, которая включает в себя структурные формулы и данные об активностях известных биологически активных соединений.

По проведенным расчетам согласно программы PASS результат прогноза биологической активности конъюгата инулина с таурином можно наблюдать в следующей таблице.

Таблица 1

Результаты расчета прогнозируемой биологической активности конъюгата инулина с таурином по отношению к биологической активности инулина

\begin{tabular}{|c|c|c|c|}
\hline \multirow{2}{*}{$\begin{array}{c}\text { Вид биологической } \\
\text { активности }\end{array}$} & \multicolumn{2}{|c|}{$\begin{array}{c}\text { Значение вероятности наличия активности } \\
\text { в }\end{array}$} & \multirow{2}{*}{$\begin{array}{c}\text { Вероятность наличия } \\
\text { биологической активности в } \\
\text { конъюгате инулина, \% }\end{array}$} \\
\hline & $\begin{array}{c}\text { конъюгате инулина с } \\
\text { таурином }\end{array}$ & инулине & \\
\hline $\begin{array}{c}\text { Стимулятор агрегации } \\
\text { тромбоцитов }\end{array}$ & 0.466 & 0.364 & Усилено на 10,2\% \\
\hline Стимулятор лейкопоэза & 0.346 & 0.283 & Усилено на $6,3 \%$ \\
\hline Радиосенсибилизирующая & 0.332 & 0.290 & Усилено на 4,2\% \\
\hline Хемосенсибилизатор & 0.372 & 0.339 & Усилено на 3,3\% \\
\hline $\begin{array}{l}\text { Лечение фобических } \\
\text { расстройств }\end{array}$ & 0.493 & не проявляет & 49,3 \\
\hline
\end{tabular}

На основе результатов прогноза биологической активности конъюгата инулина с таурином, введение в структуру полисахарида низкомолекулярного фрагмента таурина положительно влияет на представленные в таблице виды 
биологической активности, и способствует возникновению такой активности, как лечение фобических расстройств.

\section{Литература:}

1. Иозеп А.А., Бессонова Н.К., Пассет Б.В. Синтез сложных эфиров карбоксиэтилполисахаридов. // ЖПХ. 1998. - Т.71. - №6. - С.995-998.

2. Карасева А.Н., Миронов В.Ф., Цепаева О.В., Выштакалюк А Б., Минзанова С.Г., Карлин В.В., Миндубаев А.З. Полиметаллокомплексы пектиновых полисахаридов и их биологическая активность. // Химия и компьютерное моделирование. Бутлеровские сообщ. - 2004. - Т. 5, № 1. - С. 33-35.

3. Интернет-ресурс Энциклопедия лекарств и товаров аптечного ассортимента http://www.rlsnet.ru

4. Никитина В.С., Яминева Э.3. «Химическая модификация полифруктозана инулина органическими кислотами» - Тезисы докладов XVI Международной научно-технической конференции Приоритетные направления развития науки и технологии (г. Тула, 25 декабря 2014 г.), C.24-26.

5. Садым А.В., Лагунин А.А., Филимонов Д.А., Поройков В.В. Интернетсистема прогноза спектра биологической активности химических соединений // Химико-технологический журнал. 2002. Т. 36. №10. С.21-26. 